\title{
Peran Waktu Inokulasi Meloidogyne dalam Meningkatkan Infeksi Patogen Busuk Pangkal pada Bawang Putih
}

\section{Role Inoculation Time of Meloidogyne in Enchancing Infection of Basal Rot Pathogen on Garlic}

\author{
Budi Handayani $^{1)}$, Hadiwiyono ${ }^{2)}$, Subagiya ${ }^{2)}$
}

\begin{abstract}
Basal rot was an important disease in garlic caused by Fusarium oxysporum $f$. sp. cepae (FOCe) and a major obstacle in garlic cultivation. Root knot nematodes (Meloidogyne) is endoparasitic nematodes causing plants become more susceptible to fungal pathogen infection. This research aimed to study the effect of double inoculation FOCe and Meloidogyne, and current inoculation against disease severity of basal root. The research was conducted through experimental procedures and prepared based on a randomized complete block design, with two factors consisting of three levels inoculation time. The first factor was FOCe and the second factor was Meloidogyne. The results showed that Meloidogyne presence could increase the disease severity of basal rot of garlic. Garlic was inoculated at 35 days after planting (dap) by Meloidogyne and FOCe cause the most severe disease of basal rot.
\end{abstract}

Keywords : Meloidogyne, rot, pathogen, garlic

\section{PENDAHULUAN}

Bawang putih merupakan komoditas pertanian penting, namun produksi bawang putih dalam negeri belum dapat memenuhi permintaan pasar. Masalah yang dihadapi dalam budidaya bawang putih adalah penyakit busuk pangkal yang disebabkan Fusarium oxysporum f. sp. cepae (FOCe) yang merupakan penyebab berkurangnya hasil bawang putih, selama di lahan maupun selama penyimpanan. Busuk pangkal yang disebabkan FOCe dilaporkan menjadi salah satu faktor penting penyebab kehilangan hasil bawang putih sejak 1973 (Widodo et al. 2008).

Pada dasa warsa terakhir ini, FOCe telah menjadi patogen yang penting pada bawang putih (Allium sativum L.) di Tawangmangu Karanganyar, Jawa Tengah. Di lahan tertentu, penyakit bersifat endemi dengan insidens penyakit dapat mencapai $60 \%$, sedangkan di beberapa daerah lainnya patogen bersifat nonendemi dengan insidensi penyakit kurang dari 5\% (Fatawi et al. 2003) Lebih dari $92 \%$ lahan penanaman bawang putih di daerah Tawangmangu telah terjangkit FOCe (Hadiwiyono et al. 2009).

Di antara berbagai hama dan penyakit, kompleks penyakit Meloidogyne sp. dan FOCe menimbulkan masalah besar untuk budidaya tanaman dengan menimbulkan kehilangan hasil yang parah. Meloidogyne sp. merupakan endoparasit menetap dan termasuk yang paling parah menimbulkan kerusakan tanaman, menyerang berbagai tanaman. FOCe jamur deutromycetous, menyebabkan layu hingga kematian pada tanaman. Kerugian akibat

\footnotetext{
1) Undergraduate Student of Study Program of Agrotechnology, Faculty of Agriculture University of Sebelas Maret (UNS) in Surakarta.

${ }^{2)}$ Lecturer of Study Program of Agrotechnology, Faculty of Agriculture University of Sebelas Maret (UNS) in Surakarta.
}

Contact Author: hadi_hpt@yahoo.com jamur ini telah dilaporkan pada berbagai tanaman (Mahapatra dan Swain 2004).

Penelitian bertujuan untuk mempelajari pengaruh keberadaan Meloidogyne terhadap keparahan penyakit busuk pangkal bawang putih yang disebabkan oleh $F$. oxysporum f. sp. cepae dan saat inokulasi yang dapat menimbulkan busuk pangkat yang lebih parah.

\section{METODE PENELITIAN}

Penelitian ini telah dilaksanakan pada bulan Mei sampai September 2013 bertempat di Gondosuli, Tawangmangu, Karanganyar dan di Laboratorium Hama dan Penyakit Tanaman Fakultas Pertanian Universitas Sebelas Maret Surakarta.

Penelitian dilaksanakan secara eksperimen disusun menggunakan rancangan acak kelompok lengkap, dengan dua faktor perlakuan yaitu inokulasi Fusarium oxysporum dan inokulasi Meloidogyne. Inokulasi Fusarium oxysporum terdiri atas tiga taraf yakni F0 : tanpa inokulasi, F35: inokulasi pada 35 hst, F49: inokulasi pada 49 hst. Inokulasi Meloidogyne juga terdiri atas tiga taraf yaitu M0: tanpa inokulasi, M35: inokulasi pada 35 hst, M49: inokulasi pada 49 hst. Sehingga diperoleh 9 kombinasi perlakuan yang diulang sebanyak tiga kali ulangan.

Variabel pengamatan terdiri dari masa inkubasi, intensitas dan insiden kelayuan dan busuk umbi, laju infeksi penyakit, AUDPC, dan jumlah akhir Meloidogyne.

Insiden layu dan busuk umbi dihitung dengan menggunakan rumus sebagai berikut:

$$
\text { Insidens Penyakit }=\frac{j \text { jumlah tanaman sakit }}{\text { jumlah seluruh tanaman }} \times 100 \%
$$


Sedangkan intensitas layu dan busuk umbi dihitung menggunakan rumus sebagai berikut:

$$
\text { lntensitas Penyakit }=\frac{\sum(n x w)}{\mathbb{N} x Z} \times 100 \%
$$

dengan $n=$ jumlah tanaman yang diamati menunjukkan skor tertentu; $v=$ skor untuk tanaman yang mengalami gejala kelayuan; $N=$ skor tertinggi; dan $Z$ = jumlah seluruh tanaman yang diamati.

Ketentuan skoring yang digunakan adalah $0=$ tanaman tidak menunjukan gejala; $1=1-25 \%$ daun layu/umbi busuk ; $2=26-50 \%$ daun layu/umbi busuk; $3=51-75 \%$ daun layu/umbi busuk; dan $4=76-100 \%$ daun layu/umbi busuk.

Laju Infeksi Penyakit dihitung secara mingguan, menggunakan rumus sebagai berikut:

$$
r=\frac{2.3}{t}\left(\log \frac{1}{1-x t}-\log \frac{1}{1-X_{0}}\right)
$$

dengan $r=$ laju infeksi penyakit (per unit per minggu); $t=$ interval waktu pengamatan (mingguan); $X O=$ proporsi penyakit pada awal pengamatan; dan $X t=$ proporsi penyakit pada pengamatan ke $t$.

Nilai Area of Under the Disease Progress Curve (AUDPC) diperoleh dari hasil pengamatan insidens penyakit. Dihitung dengan rumus:

$$
A U D P C=\sum_{n-1}^{i=1}\left[\frac{x i+X i+1}{2}\right] \times \mathrm{t}_{i+1}-\mathrm{t}_{i}
$$

dengan $x=$ insidens penyakit, dan $t=$ waktu pengamatan (minggu ke-1, 2, 3 , dan seterusnya)

Analisis data hasil penelitian ini menggunakan analisis ragam dengan uji $F$ taraf 0,05 . Apabila terdapat beda nyata dilanjutkan dengan uji jarak berganda Duncan (Duncan's Multiple Range Test/DMRT).

\section{HASIL DAN PEMBAHASAN}

\section{Intensitas dan Insidens Layu Busuk Pangkal Bawang Putih}

Inokulasi ganda FOCe dan Meloidogyne memberikan pengaruh yang signifikan $(P<0.05)$ terhadap intensitas dan insidens kelayuan akibat
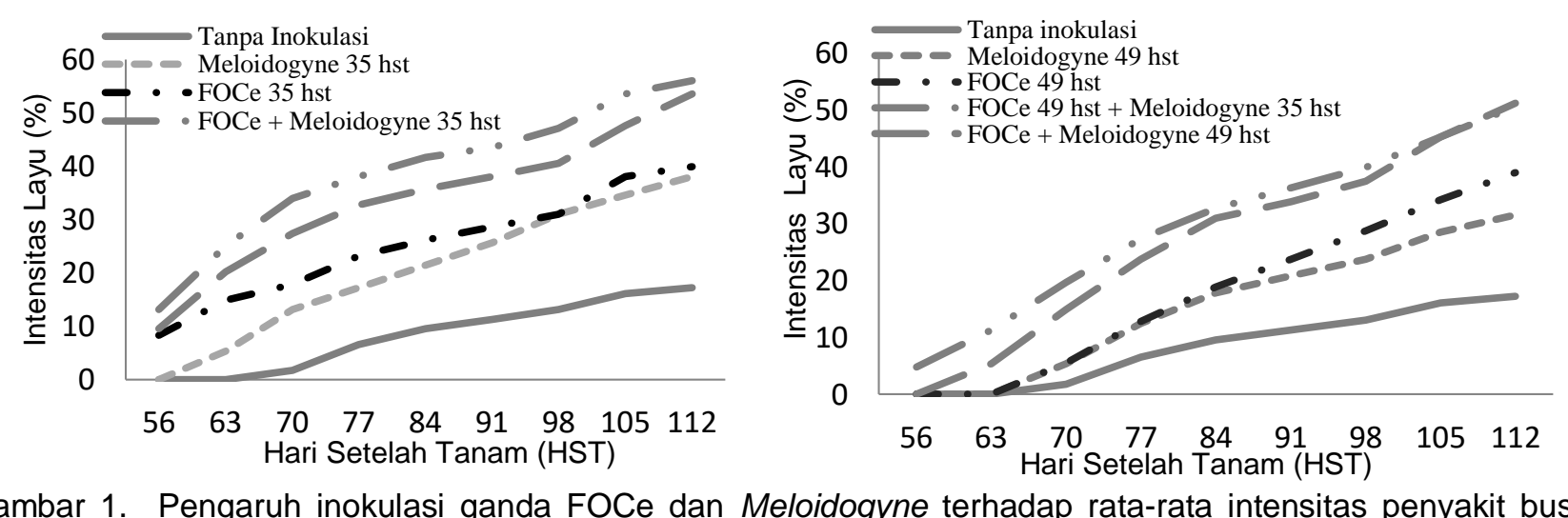

Gambar 1. Pengaruh inokulasi ganda FOCe dan Meloidogyne terhadap rata-rata intensitas penyakit busuk pangkal bawang putih

Selain intensitas layu, inokulasi ganda juga meningkatkan insidens layu. Bawang putih yang diinokulasi FOCe dan Meloidogyne semua tanaman mengalami layu atau insidens sebesar 100\%. Sedangkan bawang putih tanpa inokulasi insidens serangan FOCe. Gambar 1 menunjukkan bahwa inokulasi ganda FOCe dan Meloidogyne mengalami insidens dan keparahan yang lebih tinggi dibanding inokulasi tunggal dari masing-masing patogen.

Inokulasi FOCe dan Meloidogyne menyababkan intensitas layu paling tinggi yakni hingga $55,95 \%$ pada pengamatan 112 hst. Hasil ini jauh lebih tinggi dari bawang putih yang tanpa inokulasi yang hanya $17,26 \%$ atau meningkat sebesar $38,69 \%$. Inokulasi FOCe secara tunggal menimbulkan Intensitas layu paling tinggi $39,88 \%$ atau dengan kata keberadaan Meloidogyne meningkatkan layu $16,06 \%$. Hal ini menunjukan bahwa inokulasi ganda menyebabkan peningkatan keparahan busuk pangkal bawang putih. Inokulasi 35 hst menimbulkan intensitas layu peling tinggi $55,95 \%$, sedangkan perlakuan 49 hst menimbulkan intensitas $51,19 \%$. Inokulasi pada 35 hst menimbulkan layu yang lebih parah dibandingkan 49 hst. Hasil ini sejalan dengan pernyataan Castillo et al. (2003) Infeksi nemotada puru akar secara signifikan mempengaruhi insidens penyakit, keparahan, masa inkubasi, dan kehilangan hasil akibat layu Fusarium. Son et al. (2009) juga mnegungkpakan bahwa tingkat keparahan layu akibat Fusarium akan meningkat ketika diinokulasi Meloidogyne secara bersamaan. Peningkatan intensitas layu ini disebabkan keberadaan luka pada akar akibat serangan Meloidogyne sehingga akan mempermudah FOCe untuk menginfeksi.

Gambar 1, menunjukkan waktu inokulasi ganda yang menyebabkan intensitas layu paling parah adalah inokulasi FOCe dan Meloidogyne pada 35 hst yakni sebesar $55,95 \%$. Inokulasi FOCe 35 hst disusul sebesar $57,14 \%$ dan inokulasi FOCe saja insidens paling tinggi sebesar $92,85 \%$. Waktu inokulasi tidak berpengaruh terhadap insidens layu karena semua perlakuan ganda menimbulkan insidens layu sebesar $100 \%$.

\section{Masa Inkubasi Busuk Pangkal Bawang Putih}

Masa inkubasi merupakan periode atau selang waktu antara terjadinya infeksi patogen pada tanaman hingga menimbulkan gejala pertama kali. Inokulasi ganda dengan saat inokulasi FOCe dan Meloidogyne 
secara signifikan $(P<0.05) \quad$ mempengaruhi masa inkubasi. Menurut Widjaja dan Hadisoeganda (1995) inokulasi FOCe dan Meloidogyne dapat mempersingkat masa inkubasi layu Fusarium dari 25 hari menjadi 14 hari. Nurul dan Tietik (2010) juga

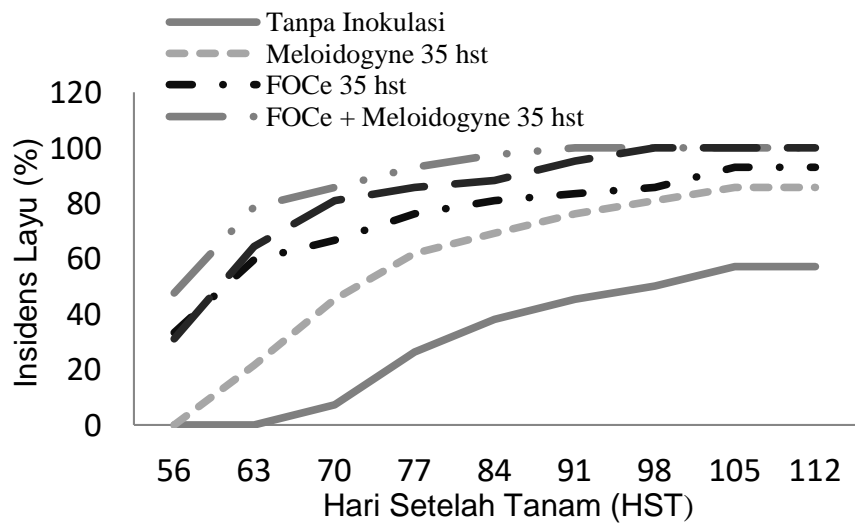

menyatakan bahwa masa inkubasi penyakit dipengaruhi oleh umur tanaman saat diinokulasi. Tanaman yang lebih muda mempunyai masa inkubasi yang lebih cepat dibandingkan dengan tanaman yang tua.

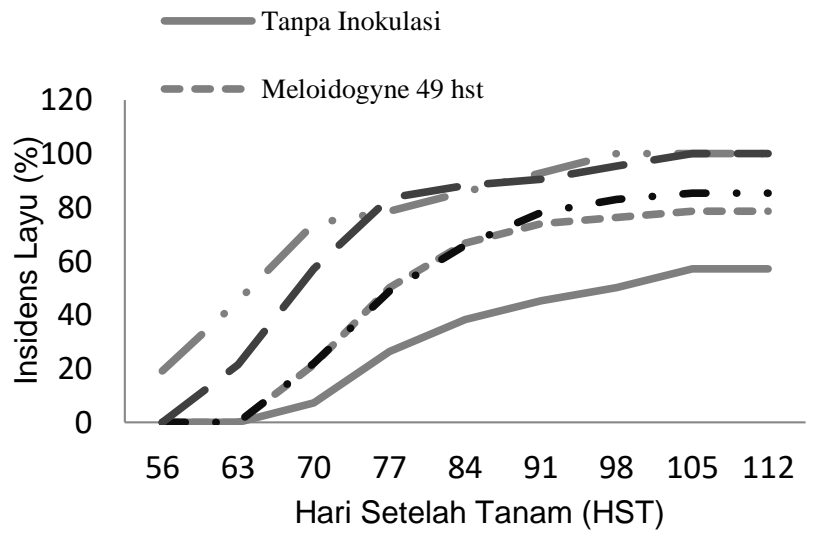

Gambar 2. Pengaruh inokulasi ganda F. oxysporum f. sp. cepae dan Meloidogyne terhadap rata-rata insidens penyakit busuk pangkal bawang putih tiap minggu

Gambar 3 menunjukkan bahwa perlakuan ganda FOCe dan Meloidogyne memiliki masa inkubasi paling singkat yakni 7 hari setelah inokulasi gejala layu sudah muncul. Inokulasi FOCe saja gejala layu paling cepat mundul pada 9 hari setelah inokulasi, sedangkan bawang putih tanpa inokulasi masa inkubasi layu selama 25 hari terhitung dari 49 hst atau pada umur 74 hst.

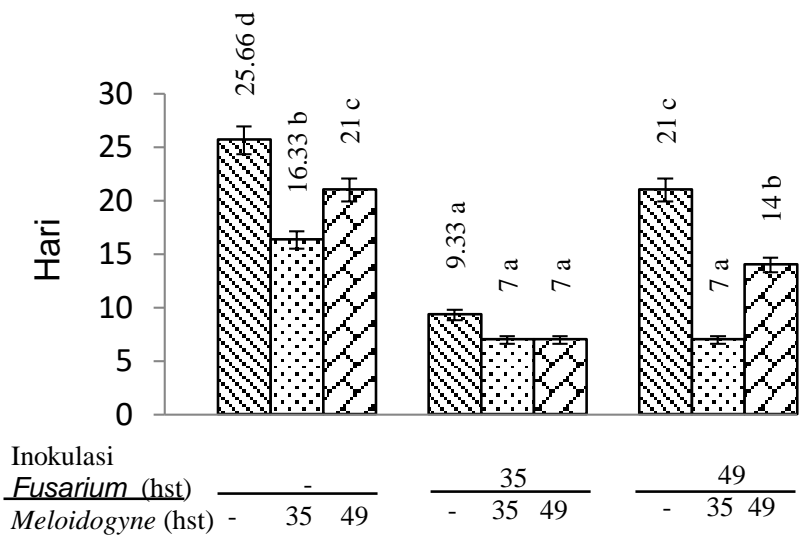

Gambar 3. Pengaruh inokulasi ganda dengan saat inokulasi FOCe dan Meloidogyne terhadap masa inkubasi busuk pangkal bawang putih

\section{Area of Under the Disease Progress Curve (AUDPC) Penyakit Busuk Pangkal Bawang Putih}

Inokulasi ganda dengan saat inokulasi FOCe dan Meloidogyne memberikan pengaruh yang nyata $(\mathrm{P}<0.05)$ terhadap nilai AUDPC busuk pangkal bawang putih. Jumjunidang et al. (2009) menyatakan bahwa tanaman terserang Meloidogyne akan mengalami perubahan kimia pada akarnya. Asam amino akan meningkat $700 \%$, dimana asam amino

\section{Laju Infeksi Penyakit Busuk Pangkal Bawang Putih}

Laju infeksi merupakan jumlah pertambahan infeksi per satuan waktu. Laju infeksi pada inokulasi ganda menunjukan percepatan perkembangan penyakit. Haseeb et al. (2005) menyatakan bahwa inokulasi nematoda dengan Fusarium mengakibatkan perkembangan penyakit akan lebih cepat dan menimbulkan tingkat serangan Fusarium menjadi lebih berat apabila dibanding dengan inokulasi tunggal

Gambar 4 menunjukkan minggu-minggu awal setelah inokulasi terjadi perkembangan penyakit telah mencapai puncak, hal ini menyebakan kerusakan ketika tanaman masih muda dan akibatnya tidak terbentuk umbi. Inokulasi ganda FOCe dan Meloidogyne pada 63 hst telah mencapai puncak laju penyakit sedangkan perlakuan lain rata-rata pada 70 hingga 80 hst. Inokulasi ganda pada 35 hst mengalami puncak laju infeksi pada umur bawang putih 63 hst dengan laju infeksi sebesar 0,147, hal ini menunjukan perlakuan tersebut paling cepat mengalami kelayuan dengan intensitas yang parah. Sedangkan inokulasi FOCe dan Meloidogyne tidak bersamaan laju infeksinye lebih rendah dari inokulasi secara bersamaan pada $35 \mathrm{hst}$.

merupakan sumber nutrisi berenergi tinggi bagi Fusarium. Sehingga perkembangan Fusarium akan lebih pesat.Inokulasi FOCe dan Meloidogyne 35 hst menunjukan nilai AUDPC paling tinggi yakni 7,28 atau berarti bawang putih mengalami layu paling parah selama rentang waktu setalah inokulasi hingga panen. Sementara itu inokulasi ganda dengan FOCe terlebih dahulu atau Meloidogyne terlebih dahulu nilai AUDPC tidak berbeda secara signifikan yakni 6,79 dan 6,36. 

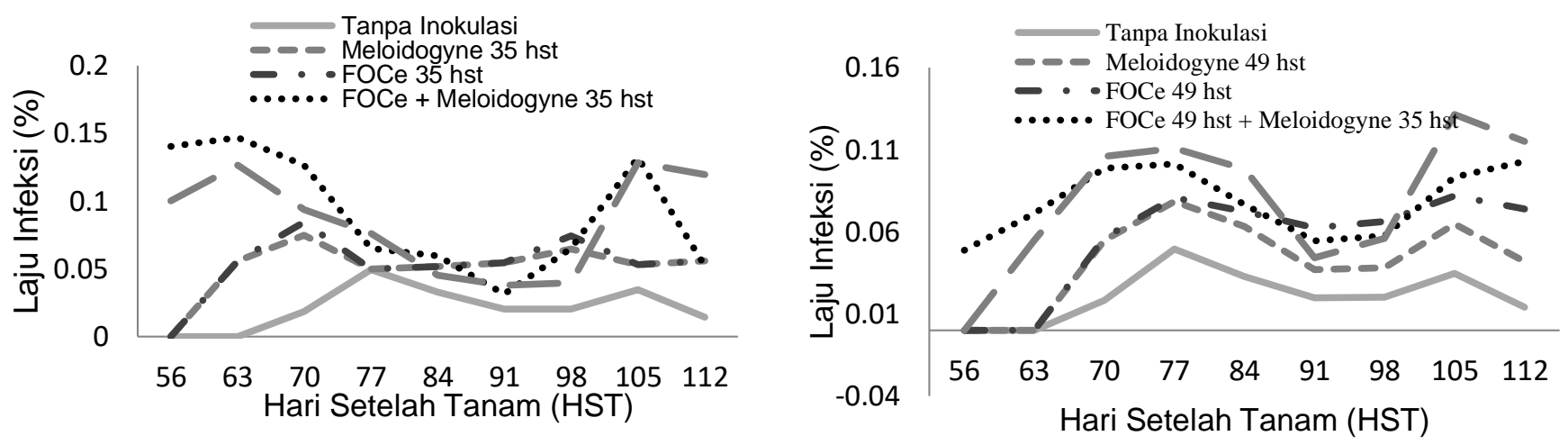

Gambar 4. Pengaruh inokulasi ganda F. oxysporum f. sp. cepae dan Meloidogyne terhadap rata-rata laju infeksi penyakit busuk pangkal bawang putih tiap minggu

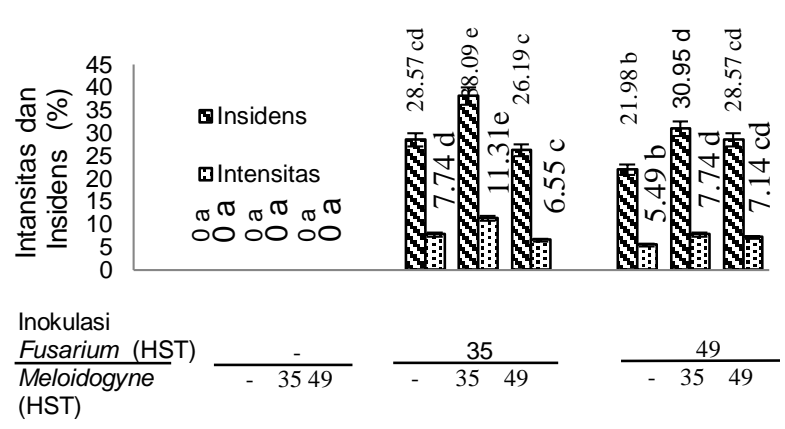

Gambar 5. Pengaruh inokulasi ganda F. oxysporum f.sp. cepae dan Meloidogyne terhadap LBKPP penyakit busuk pangkal bawang putih

Intensitas dan Insidens Busuk Umbi Penyakit Busuk Pangkal Bawang Putih

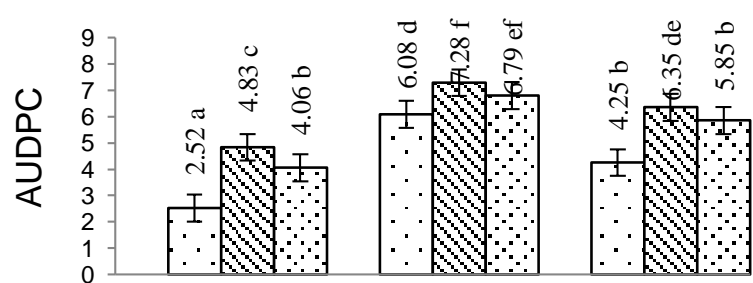

Inokulasi

Fusarium (hst)

Meloidogyne (hst)

$\frac{0}{0 \quad 3549}$

$\frac{35}{-3549}$

$\frac{49}{-3549}$

Gambar 6. Pengaruh inokulasi ganda dengan saat inokulasi FOCe dan Meloidogyne terhadap insidens dan intensitas busuk umbi bawang putih

Ganaie dan Khan (2003) menyatakan FOCe menyerang jaringan vaskuler dan mengakibatkan kelayuan pada tanaman inang, karena aliran air pada jaringan xylem terhambat. Akibatnya umbi bawang akan membusuk dan berwarnya kuning coklat, dan akhirnya menjadi "gembus". Hasil pengamatan menunjukan bahwa inokulasi ganda dengan saat inokulasi FOCe dan Meloidogyne secara signifikan $(P, 0.05)$ meningkatkan insidens dan intensitas busuk umbi pada bawang putih.

Perlakuan ganda meningkatkan intenitas busuk dan intensitas busuk umbi. Chindo et al. (2010) menyatakan bahwa jumlah insidens akan meningkat ketika tanaman diinokulasi ganda Fusarium dan Meloidogyne tanaman yang terinfeksi Fusarium meningkat dari $54 \%$ menjadi $88 \%$. Agrios (2005) menyatakan bahwa kerusakan yang ditimbulkan kompleks penyakit akibat FOCe dan Meloidogyne akan jauh lebih besar apabila dibandingkan dengan jumlah kerusakan yang disebabkan oleh masingmasing patogen tersebut apabila menyerang secara sendiri-sendiri.

Inokulasi FOCe dan Meloidogyne menimbulkan umbi busuk hingga $38,09 \%$. Inokulasi FOCe saja hanya mengalami busuk paling besar $28,57 \%$ sedang tanpa inokulasi umbi tidak ada yang mengalami kebusukan. Meskipun intensitas yang timbul kecil yakni paling tinggi $11,51 \%$ untuk inokulasi ganda dan $7,74 \%$ pada inokulasi tunggal. Kerugian akibat bawang putih dihitung dari kejadian busuk, karena bawang yang busuk sudah tidak laku dijual atau harga jual turun. Waktu inokulasi ganda yang menyebabkan busuk umbi paling banyak adalah inokulasi FOCe dan Meloidogyne pada 35 hst yakni insiden busuk $38,08 \%$. Sementara itu inokulasi Meloidogyne dahulu insidens busuk $30,95 \%$. Inokulasi FOCe dahulu insidens busuk $26,19 \%$. Inokulasi secara bersamaan pada 49 hst insidens busuk $28,57 \%$.

\section{KESIMPULAN DAN SARAN}

\section{Kesimpulan}

1. Keberadaan Meloidogyne meningkatkan keparahan busuk pangkal bawang putih yang disebabkan F. oxysporum f. sp cepae .

2. Inokulasi F. oxysporum f. sp cepae dan Meloidogyne pada 35 hari setelah tanam menimbulkan busuk pangkal bawang putih dengan

\section{Saran}

Berdasarkan penelitian yang telah dilaksanakan disarankan dalam penelitian bawang putih selanjutnya sebaiknya penanaman dilakukan pada rumah kaca atau screen house mengingat bawang putih yang rentan terhadap curah hujan tinggi. Perlunya uji lanjutan dengan variasi waktu yang lebih banyak tidak hanya 35 dan 49 hari setelah tanam. 


\section{DAFTAR PUSTAKA}

Agrios GN. 2005. Plant pathology. 4th Ed. San Diego (US): Elsivier Academic Press.

Castillo P, Navas-Cortés JA, Gomar-Tinoco D, Vito MD, Jiménez-Díaz RM. 2003. Interaction between meloidogyne artiellia, the cereal and legume rootknot nematode, and fusarium oxysporum f.sp. Ciceris race 5 in chickpea. phytopathol 93(12): 1513-1523.

Chindo PS, Shebayan Jay, Marley PS. 2010. Effect of pre-emergence herbicide on Meloidogyne spp. and Fusarium wilt of tomato in Samaru, Zaria, Nigeria. J Agric Res 48(4): 489-495.

Fatawi ZD, Gutomo HS, Hadiwiyono. 2003. Studi lini dasar terjadinya epidemi penyakit busuk pangkal bawang putih di tawangmangu. laporan hasil penelitian sumber dana due-like. Program Studi Agronomi. Fakultas Pertanian. UNS. 45 hal.

Ganaie MA, Khan TA. 2011. Studies on the interactive effect of Meloidogyne incognita and Fusarium solani on Lycopersicion esculentum, Mill. Int J Bot 10: 1-4.

Hadiwiyono, Wuspada RD, Widono S, Poromarto SH, Fatawi ZD. 2009. Kesupresifan tanah terhadap busuk pangkal (Fusarium oxysporum f.sp.cepae) bawang putih di Tawangmangu, Karanganyar (ID): Sains Tanah 6(1): 1-6.

Haseeb A, Sharma A, Shukla PK. 2005. Studies on the management of root-knot nematode,
Meloidogyne incognita-wilt fungus, fusarium oxysporum disease complex. J Zhejiang Univ SCl 6B(8): 736-742.

Jumjunidang, Andinata Y, Sulyanti E. 2009. The effect of initial population of radopholus similis to induce Fusarium oxysporum f.sp. cubense race 4 on banana cv. Ambon Hijau. Agrivita 13(1): 48-56.

Mahapatra SN, Swain PK. 2004. Interaction between Meloidogyne incognita and Fusarium oxysporum on blackgram. Annals of PI Protect Sci 9: 92-94.

Nurul H, Tietik Y. 2010. Pengaruh waktu inokulasi dan jumlah inokulum terhadap patogenesitas phytoptora nicotianae pada bibit tembakau. Buletin Tanaman Tembakau, Serat \& Minyak Industri 2(2): 75-80.

Son SH, Khan Z, Kimand SG, Kim YH. 2009. Plantgrowth-promoting rhizobacteria, Paenibacillus polymyxa and Paenibacillus lentimorbus suppress disease complex caused by root-knot nematode and Fusarium wilt fungus. J Appl Micro 107: 524532.

Widjaja A, Hadisoeganda W. 1995. Interaksi kultivar tomat tahan cendawan layu Fusarium terhadap nematode bengkak akar dan cendawan layu. J Hort 5(3): 40-45.

Widodo, Kondo N, Kobayashi K, Ogoshi A. 2008. Vegetative compatibility groups within Fusarium oxysporum f. sp. cepae in Hokkaido-Japan. J Mikro Ind 2(1): 39-43. 